\title{
Hubungan Pemantauan Pertumbuhan Anak Baduta pada Masa Pandemi COVID-19 dan Sumber Informasi Ibu Tentang MP-ASI dengan Status Gizi
}

\author{
Maria Galuh Kamenyangan Sari*, Vitri Widyaningsih, \\ Meirina Mulia Wardani, Alamanda Murasmita, Afif Avicenna Ghufron \\ Rumah Sakit Universitas Sebelas Maret, Fakultas Kedokteran Universitas Sebelas Maret \\ E-mail: maria.galuh@staff.uns.ac.id
}

\begin{abstract}
Abstrak
Kejadian kasus Covid-19 pada anak hingga bulan Oktober 2020 dilaporkan mencapai lebih dari 37.000 kasus. Ketepatan pemberian makanan pendamping ASI (MP-ASI) saat periode emas di bawah dua tahun menjadi prioritas penting menjaga imunitas sejak dini sebagai bentuk preventif infeksi termasuk virus Covid-19. Pemantauan pertumbuhan anak bawah dua tahun (baduta) pada era pandemi menjadi hal yang utama untuk mendeteksi dini malnutrisi dan penatalaksanaannya. Penelitian ini bertujuan mengetahui hubungan pemantauan pertumbuhan anak baduta dan sumber informasi ibu tentang MP-ASI dengan status gizi serta penyuluhan sebagai pengabdian masyarakat. Penelitian observasional analitik dengan desain cross-sectional ini dilakukan di poliklinik anak Rumah Sakit Universitas Sebelas Maret pada bulan Agustus-Oktober 2020. Sebanyak 75 ibu memenuhi kriteria inklusi dengan metode konsekutif sampling. Pengukuran antropometri berat badan dan tinggi badan dilakukan pada semua anak kemunian ditentukan status gizinya dengan program WHO Anthro versi 3.2.2. Sebagian besar sumber pengetahuan ibu tentang MP-ASI didapatkan dari media sosial elektronik $(38,7 \%)$ dan pelayanan kesehatan lanjut (37,3\%). Sebanyak 46,7\% ibu menggunakan buku KIA untuk memantau pertumbuhan baduta dan 14,7\% ibu sudah menggunakan aplikasi Primaku. Pemantauan pertumbuhan baduta di era pandemi Covid-19 berhubungan secara signifikan dengan status gizi $(\mathrm{p}=0,010)$, meskipun tidak ada hubungan antara sumber informasi ibu tentang MPASI dengan status gizi baduta. Maka dari itu perlunya pelatihan bagi ibu maupun kader posyandu tentang praktik pemberian MP-ASI dan metode pemantauan pertumbuhan anak baduta secara berkala.
\end{abstract}

Kata Kunci: pemantauan pertumbuhan, baduta, pengetahuan ibu, MP-ASI, status gizi

\section{Pendahuluan}

Golden age (periode emas) merupakan periode yang sangat penting sejak janin sampai usia dua tahun. Pada dua tahun pertama kehidupan tersebut terjadi proses pertumbuhan dan perkembangan tubuh yang dimulai sejak janin. Jika pemenuhan gizi pada masa tersebut baik, maka proses pertumbuhan dan perkembangan dapat optimal. Jika kebutuhan zat gizi kurang maka dapat berisiko menimbulkan gangguan pertumbuhan dan perkembangan pada seluruh organ dan sistem tubuh sehingga akan berdampak pada masa yang akan datang (Adriani dan Wirjatmadi, 2014).

Ketidaktahuan ibu dalam memberikan MP-ASI yang tepat dapat menyebabkan kesulitan makan yang berdampak terhadap status gizi anak. Pada anak usia 6 bulan hingga 23 bulan sangat dianjurkan untuk memperoleh MP- ASI karena masa ini merupakan masa rawan pertumbuhan. Apabila anak mengalami kesulitan dalam menerima MPASI maka dapat terjadi hambatan dalam masa peralihan ke dalam makanan keluarga serta terjadi malnutrisi yang menjadi penyebab terbanyak kematian pada balita (Mexitalia dan Nasar, 2006).

Pada masa pandemi Covid-19 sulit untuk melakukan deteksi dini pertumbuhan anak, karena terbatasnya layanan fasilitas kesehatan dasar seperti posyandu. Maka pengetahuan ibu tentang MP-ASI dan pemantauan pertumbuhan anak secara mandiri sangat penting untuk mendeteksi dini terjadinya malnutrisi pada anak terutama pada rentang usia 4-24 bulan (Akseer, dkk., 2020). 
Jurnal SEMAR Vol. 10 No. 1, hal. $70-77$

ISSN: 2302-3937 | Copyright (C LPPM Universitas Sebelas Maret Homepage: https://jurnal.uns.ac.id/jurnal-semar

\section{Metode Pelaksanaan}

Penelitian ini bertujuan untuk mengetahui hubungan pengetahuan ibu tentang MP-ASI serta pemantauan pertumbuhan baduta di masa pandemi Covid-19 di area Solo Raya. Penelitian ini merupakan penelitian observasional analitik dengan desain cross-sectional yang dilakukan di poliklinik anak Rumah Sakit Universitas Sebelas Maret (RS UNS) pada rentang bulan Agustus-Oktober 2020. Populasi dalam penelitian ini adalah pasien anak usia 4-24 bulan yang tidak memiliki kelainan kongenital atau penyakit lain yang mengganggu proses pemberian asupan makanan.

Tahapan pelaksanaan

a. Penelitian ini telah mendapatkan persetujuan dari Komisi Etik Penelitian Kesehatan Masyarakat RSUD Dr. Moewardi Surakarta dengan nomor 1.219/X/HREC/2020 yang dikeluarkan pada tanggal 26 Oktober 2020.

b. Ibu diberi kuesioner tentang karakteristik, praktik pemberian MP-ASI serta pemantauan pertumbuhan yang diterapkannya kemudian semua populasi dilakukan pengukuran antropometri untuk menentukan status gizinya.

c. Pengukuran berat badan badutamenggunakan digital scale dengan ketelitian $1,0 \mathrm{~kg}$, dilanjutkan dengan pengukuran panjang/tinggi badan dengan menggunakan measure met Seca® 412 dilakukan oleh dua orang pengukur. kemudian membaca hasil pengukuran dengan ketelitian $0,5 \mathrm{~cm}$.

d. Penghitungan indeks antropometri berdasarkan usia, jenis kelamin, berat badan dan panjang badan dengan entry hasil pengukuran kedalam software WHO Anthro versi 3.2.2 kemudian dapat diketahui nilai Z-score status gizi berat badan terhadap panjang badan. Status gizi ditentukan dari data antropometri yang kemudian diklasifikasikan menjadi menurut cara WHO (z-score) menjadi obesitas bila z-score > 3SD, gizi lebih bila $\mathrm{z}$-score 2 sampai $3 \mathrm{SD}$, gizi baik bila z-score 2 sampai -2 SD, gizi kurang bila z-score -2 sampai -3 SD dan gizi buruk bila z-score < -3 SD (Cogill, 2001; Maqbool dan Olsen, 2008).

e. Variabel dependent dalam penelitian ini adalah status gizi baduta sedangkan variabel independent dalam penelitian ini adalah karakteristik ibu (usia, pendidikan, pekerjaan dan pendapatan keluarga), pengetahuan ibu tentang praktik pemberian MP ASI serta metode pemantauan pertumbuhan.

f. Penelitian ini menggunakan data primer yaitu pengukuran berat badan, panjang badan dan wawancara menggunakan kuesioner untuk mengetahui karakteristik ibu, sumber informasi tentang praktik pemberian MP ASI serta cara pemantauan pertumbuhan yang dilakukan.

g. Wawancara kepada ibu tentang isi kuesioner dilanjutkan penyuluhan tentang praktik pemberian MP-ASI, asesmen status gizi dan upaya penatalaksanaannya sebagai pengabdian.

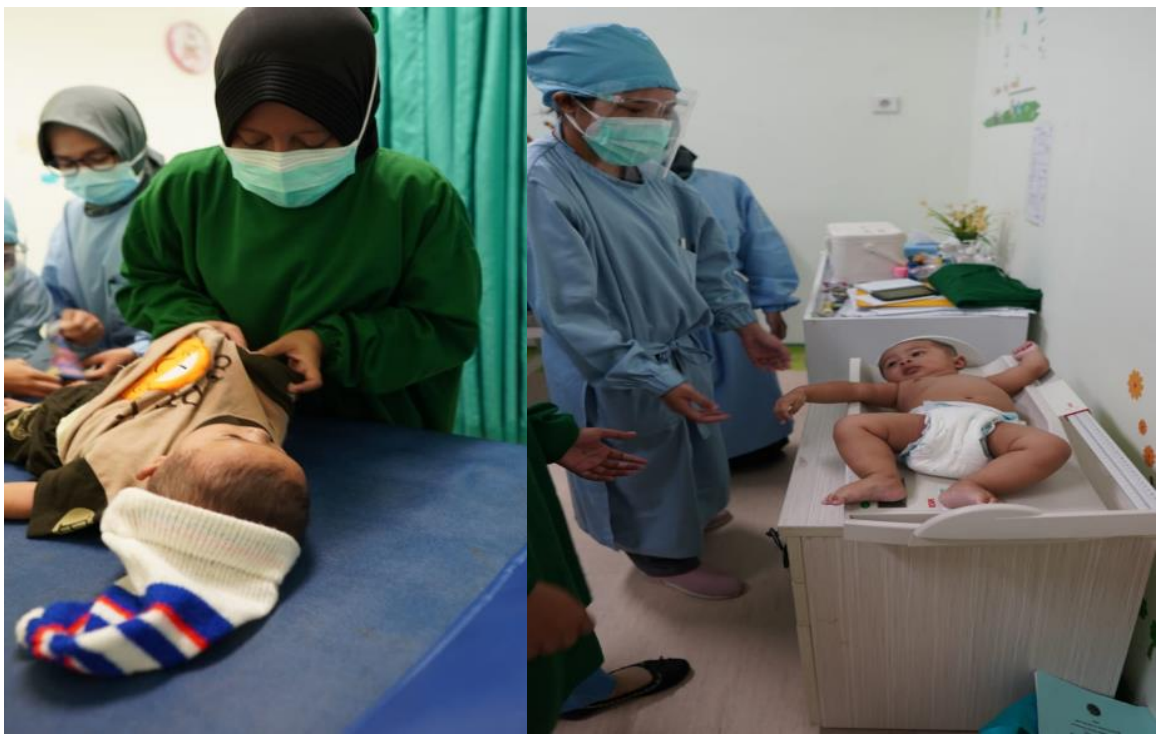

Gambar 1. Proses penimbangan berat badan 
Jurnal SEMAR Vol. 10 No. 1, hal. $70-77$

ISSN: 2302-3937 | Copyright (C LPPM Universitas Sebelas Maret Homepage: https://jurnal.uns.ac.id/jurnal-semar

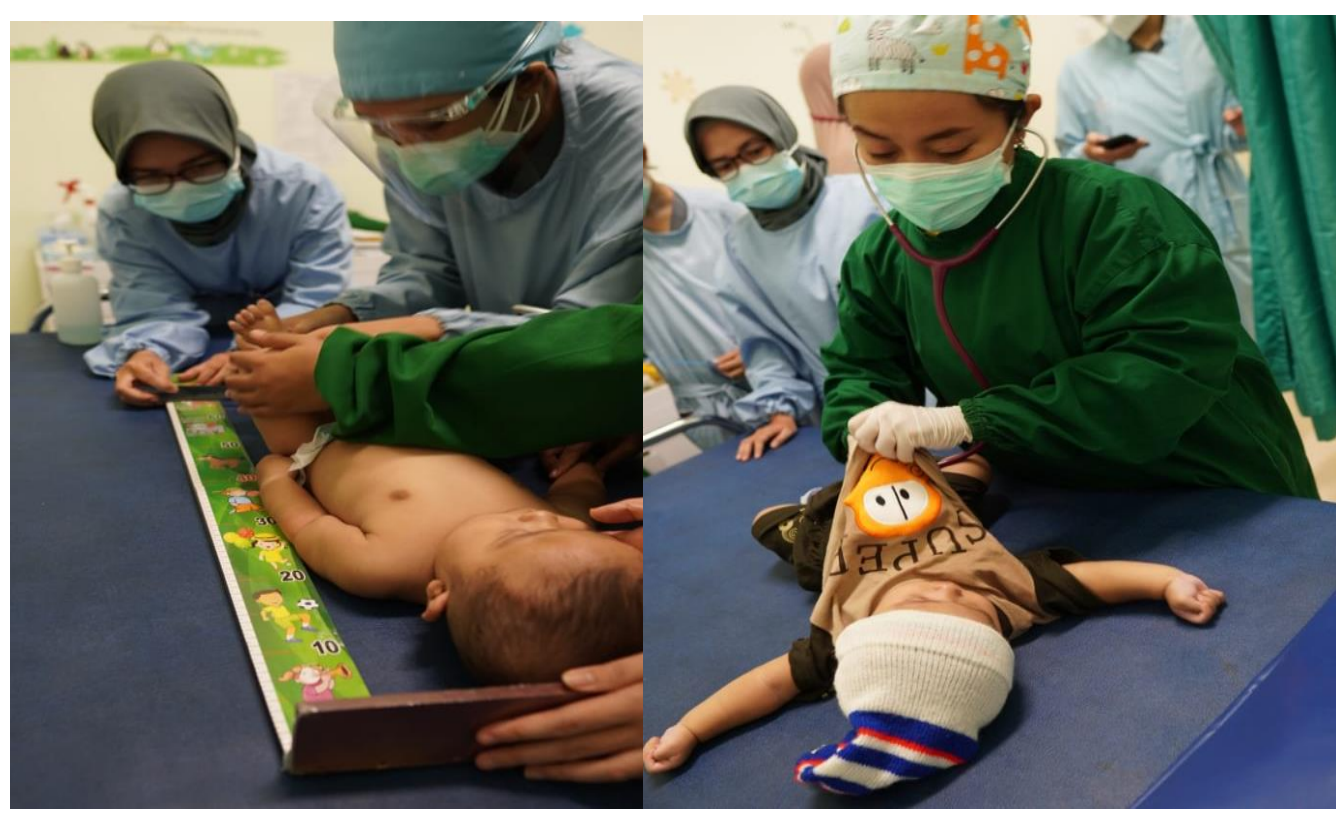

Gambar 2. Proses pengukuran panjang badan

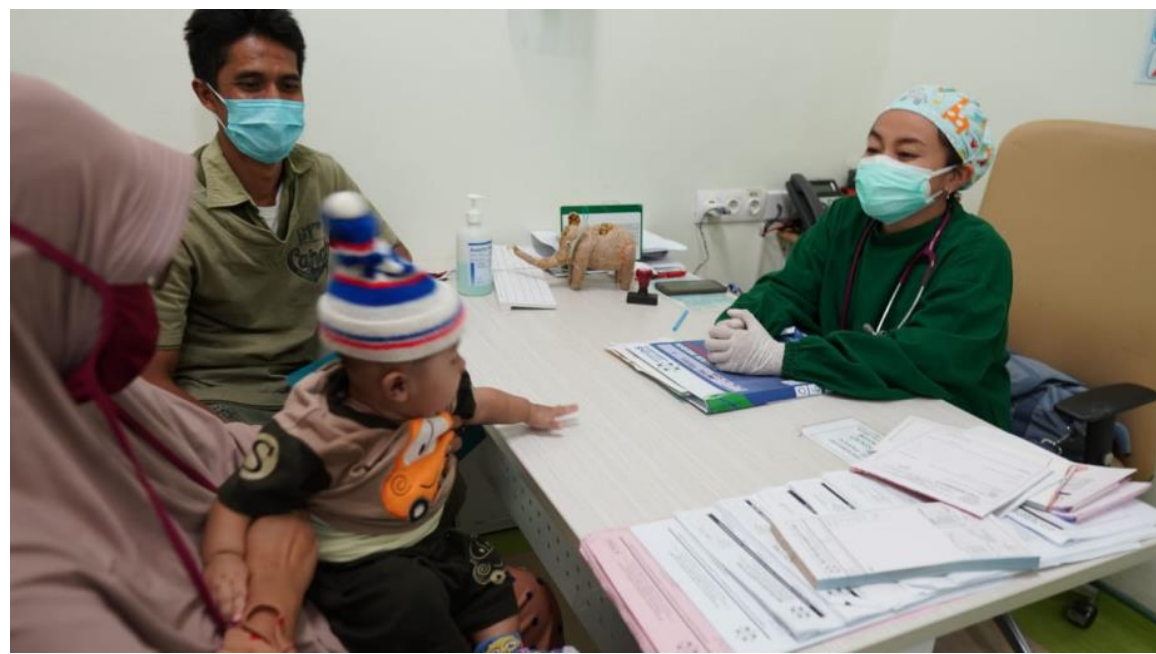

Gambar 3. Penyuluhan tentang praktik pemberian MP-ASI, asesmen status gizi dan upaya penatalaksanaannya

\section{Hasil Dan Pembahasan}

Karakteristik umum subyek penelitian merupakan gambaran secara umum dari keseluruhan sampel yang diperoleh pada penelitian tersebut, seperti yang ditunjukkan tabel 1 berikut ini:

Tabel 1. Karakteristik umum seluruh subyek penelitian

\begin{tabular}{ccc}
\hline Variabel & n & \% \\
\hline Jenis kelamin & 43 & 57,3 \\
Laki-laki & 32 & 42,7 \\
Perempuan & &
\end{tabular}


$<6$ bulan

6-9 bulan

9-12 bulan

12-18 bulan

18-24 bulan
5,3

20

20

26,7

28

$21 \quad 28$

Berat badan lahir (gram)

$$
\begin{aligned}
& <1500 \\
& 1500-2500 \\
& 2500-3500 \\
& <3500
\end{aligned}
$$$$
24
$$$$
912
$$$$
56 \quad 74,7
$$$$
7 \quad 9,3
$$

\section{Status Gizi}

Gizi lebih

10

Gizi Baik

56

Gizi Kurang

$9 \quad 12$

Berdasarkan data tersebut, total subyek yang didapatkan adalah sebanyak 75 anak, yang terdiri dari 43 (57,3\%) anak laki-laki dan 32 (42,7\%) anak perempuan dengan lebih dari separuh subyek, yakni 54,7\% merupakan kelompok usia 18-24 bulan. Dari tabel tersebut dapat dilihat bahwa mayoritas subyek lahir dengan berat badan cukup, yakni pada rentang 2500-3500 gram dan memiliki gizi baik, yaitu terdapat sebanyak 56 (74,7\%) anak. Namun demikian masih terdapat sebanyak 9 (12\%) anak yang memiliki gizi kurang.

Tabel. 1. Karakteristik umum seluruh subyek penelitian (lanjutan)

\begin{tabular}{lcc}
\hline \multicolumn{1}{c}{ Variabel } & n & $\%$ \\
Usia orang tua (tahun) & & \\
Ayah & & \\
$\quad<25$ tahun & 1 & 1,3 \\
$25-30$ tahun & 31 & 41,3 \\
$31-35$ tahun & 24 & 32,0 \\
$35-40$ tahun & 15 & 20,0 \\
$>40$ tahun & 4 & 5,3 \\
Ibu & & \\
$<25$ tahun & 3 & 2,7 \\
$25-30$ tahun & 30 & 66,7 \\
$31-35$ tahun & 13 & 17,3 \\
$35-40$ tahun & 10 & 13,3
\end{tabular}

\section{Pendidikan terakhir}

Ayah

SMP/SMA $20 \quad 26,6$

Diploma $\quad 38 \quad 50,7$

Sarjana $\quad 16 \quad 21,3$

Ibu

SMP/SMA $22 \quad 29,3$

Diploma $\quad 40 \quad 53,3$

$\begin{array}{lll}\text { Sarjana } & 14 & 18,7\end{array}$

\section{Pekerjaan Orang tua}

Ayah

Karyawan di kantor 


\begin{tabular}{lcc} 
dengan jam kerja khusus & & \\
Wiraswasta & 27 & 36 \\
Buruh & 4 & 4 \\
Dosen & 1 & 1,3 \\
$\quad$ Lain-lain & 4 & 5,2 \\
Ibu & & \\
$\quad$ Karyawan di kantor & 24 & 32 \\
$\quad$ dengan jam kerja khusus & 31 & 41,3 \\
Ibu rumah tangga & 9 & 12 \\
$\quad$ Wiraswasta & 4 & 5,3 \\
$\quad$ Bidan & 7 & 9,3 \\
$\quad$ Perawat & & \\
$\quad$ & & \\
Penghasilan Orang tua & 4 & 5,3 \\
$\quad$ Kurang dari Upah Minimum Regional & 22 & 29,3 \\
$\quad$ Sesuai denganUpah Minimum Regional & 49 & 65,3 \\
$\quad$ Lebih dari Upah Minimum Regional & & \\
\hline
\end{tabular}

Karakteristik dasar orang tua menunjukkan ayah berusia 25-30 tahun yakni 41,3\% sedangkan 50\% ibu berusia antara 31-35 tahun. Mayoritas ayah bekerja di kantor dengan jam kerja khusus sebanyak 52\% sedangkan ibu lebih banyak bekerja sebagai ibu rumah tangga yaitu 41,3\%. Pendidikan terakhir ayah dan ibu sebagian besar adalah tamatan diploma yakni sebesar 50,7\% untuk ayah dan 53,3\% untuk ibu. Penghasilan orang tua sebagian besar mendapatkan lebih dari Upah Minimum Regional (UMR) sesuai daerah masing-masing, yaitu 65,3\%, namun demikian ada $4(5,3 \%)$ subyek yang mendapatkan penghasilan di bawah UMR.

Hubungan karakteristik dasar ibu dengan status gizi anak disajikan dalam tabel 2 berikut ini:

Tabel 2. Karakteristik dasar ibu dengan status gizi anak

\begin{tabular}{|c|c|c|c|c|c|c|c|c|c|}
\hline \multicolumn{10}{|l|}{ Variabel } \\
\hline & \multicolumn{2}{|c|}{ Gizi kurang } & \multicolumn{2}{|c|}{ Gizi baik } & \multicolumn{2}{|c|}{ Gizi lebih } & \multicolumn{2}{|c|}{ Total } & \multirow[t]{2}{*}{ p value } \\
\hline & $\bar{n}$ & $\%$ & $\mathbf{n}$ & $\%$ & $\mathbf{n}$ & $\%$ & $\mathbf{n}$ & $\%$ & \\
\hline Usia Ibu & & & & & & & & & 0,440 \\
\hline$<25$ tahun & 1 & 1,8 & 1 & 11,1 & 0 & 0 & 2 & 2,7 & \\
\hline 25-30 tahun & 37 & 66,1 & 7 & 77,8 & 6 & 60 & 50 & 66,7 & \\
\hline $31-35$ tahun & 9 & 16,1 & 1 & 11,1 & 3 & 30 & 13 & 17,3 & \\
\hline 35-40 tahun & 9 & 16,1 & 0 & 0 & 1 & 10 & 10 & 13,3 & \\
\hline Pendidikan Ibu & & & & & & & & & 0,474 \\
\hline SMP/SMA & 13 & 28,6 & 3 & 33,3 & 3 & 30 & 22 & 29,3 & \\
\hline Diploma & 32 & 57,1 & 3 & 33,3 & 4 & 40 & 39 & 52 & \\
\hline Sarjana & 8 & 14,3 & 3 & 33,3 & 3 & 30 & 14 & 18,7 & \\
\hline Pekerjaan Ibu & & & & & & & & & 0,492 \\
\hline $\begin{array}{l}\text { Karyawan di kantor dengan } \\
\text { jam kerja khususkantor }\end{array}$ & 23 & 41,1 & 5 & 55,6 & 3 & 30 & 31 & 41,3 & \\
\hline dengan jam kerja & & & & & & & & & \\
\hline Ibu rumah tanggatangga & 17 & 30,4 & 4 & 44,4 & 3 & 30 & 24 & 32 & \\
\hline Wiraswasta & 6 & 10,7 & 0 & 0 & 3 & 30 & 9 & 12 & \\
\hline Bidan & 4 & 7,1 & 0 & 0 & 1 & 10 & 7 & 9,3 & \\
\hline Perawat & 6 & 10,7 & 0 & 0 & 1 & 10 & 7 & 9,3 & \\
\hline Penghasilan Keluarga & & & & & & & & & 0,671 \\
\hline$<$ UMR & 4 & 7,1 & 0 & 0 & 0 & 0 & 4 & 5,3 & \\
\hline
\end{tabular}


Jurnal SEMAR Vol. 10 No. 1, hal. $70-77$ ISSN: 2302-3937 | Copyright (C LPPM Universitas Sebelas Maret Homepage: https://jurnal.uns.ac.id/jurnal-semar

\begin{tabular}{lllllllll} 
Sesuai UMR & 15 & 26,8 & 4 & 44,4 & 3 & 30 & 22 & 29,3 \\
$>$ UMR & 37 & 66,1 & 5 & 55,6 & 7 & 70 & 49 & 65,3 \\
\hline
\end{tabular}

Hasil analisis menggunakan uji chi- square dengan nilai $\mathrm{p}=0,440(\mathrm{p}>0,05)$ yang menunjukkan bahwa tidak ada hubungan signifikan antara usia ibu balita dengan status gizi balita, demikian halnya untuk variabel independen lainnya yakni pendidikan dan jenis pekerjaan ibu serta besaran penghasilan keluarga.

Hubungan sumber pengetahuan ibu dengan status gizi anak disajikan dalam tabel 3 berikut ini

Tabel 3. Sumber informasi ibu tentang praktik pemberian MP-ASI dengan status gizi

\begin{tabular}{|c|c|c|c|c|c|c|c|c|c|}
\hline \multicolumn{10}{|l|}{ Variabel } \\
\hline & \multicolumn{2}{|c|}{ Gizi kurang } & \multicolumn{2}{|c|}{ Gizi baik } & \multicolumn{2}{|c|}{ Gizi lebih } & \multicolumn{2}{|c|}{ Total } & \multirow[t]{2}{*}{ p value } \\
\hline & $\mathbf{n}$ & $\%$ & $\mathbf{n}$ & $\%$ & $\mathbf{n}$ & $\%$ & $\mathbf{n}$ & $\%$ & \\
\hline Sumber informasi ibu & & & & & & & & & 0,240 \\
\hline Tradisi keluarga & 5 & 8,9 & 0 & 0 & 0 & 0 & 5 & 6,7 & \\
\hline $\begin{array}{l}\text { Pelayanan kesehatan dasar } \\
\text { (kader/bidan/posyandu) }\end{array}$ & 6 & 10,7 & 3 & 33,3 & 2 & 20 & 11 & 14,7 & \\
\hline Pelayanan kesehatan lanjut & 20 & 35,7 & 4 & 44,4 & 4 & 40 & 28 & 37,3 & \\
\hline Sosial media elektronik & 24 & 42,9 & 2 & 22,2 & 3 & 30 & 29 & 38,7 & \\
\hline Tabloid/majalah/koran & 0 & 0 & 0 & 0 & 1 & 10 & 1 & 1,3 & \\
\hline Berbagai sumber & 1 & 1,8 & 0 & 0 & 0 & 0 & 1 & 1,3 & \\
\hline
\end{tabular}

Jumlah ibu yang mendapat informasi tentang praktik pemberian MP ASI dari sosial media elektronik yaitu 29 $(38,7 \%)$ responden seimbang dengan perolehan informasi dari pelayanan kesehatan lanjut, baik dari RS, dokter umum maupun dokter anak sebanyak $28(37,3 \%)$ responden. Sumber perolehan informasi ibu mengenai MP-ASI tidak berhubungan signifikan dengan status gizi anak yang ditunjukkan dengan nilai $p=0,240$.

Tabel 4. Hubungan pemantauan pertumbuhan baduta dengan status gizi di masa pandemi Covid-19

\begin{tabular}{|c|c|c|c|c|c|c|c|c|c|}
\hline \multicolumn{10}{|l|}{ Variabel } \\
\hline & \multicolumn{2}{|c|}{ Gizi kurang } & \multicolumn{2}{|c|}{ Gizi baik } & \multicolumn{2}{|c|}{ Gizi lebih } & \multicolumn{2}{|c|}{ Total } & \multirow[t]{2}{*}{ p value } \\
\hline & $\mathbf{n}$ & $\%$ & $\mathbf{n}$ & $\%$ & $\mathbf{n}$ & $\%$ & $\mathbf{n}$ & $\%$ & \\
\hline $\begin{array}{l}\text { Cara pemantauan pertumbuhan (BB } \\
\text { maupun } \mathbf{T B} \text { ) }\end{array}$ & & & & & & & & & 0,010 \\
\hline Kira-kira saja dibanding anak usia sebaya & 2 & 3,6 & 3 & 33,3 & 0 & 0 & 5 & 6,7 & \\
\hline Menggunakan buku KIA & 29 & 51,8 & 1 & 11,1 & 5 & 50 & 35 & 46,7 & \\
\hline $\begin{array}{l}\text { Rutin kunjungan ke bidan/dokter } \\
\text { umum/dokter anak }\end{array}$ & 11 & 19,6 & 4 & 44,4 & 1 & 10 & 16 & 21,3 & \\
\hline Aplikasi tertentu (Primaku) & 8 & 14,3 & 0 & 0 & 3 & 30 & 11 & 14,7 & \\
\hline Timbangan sendiri di rumah & 3 & 5,4 & 1 & 11,1 & 0 & 0 & 4 & 5,3 & \\
\hline Kunjungan kader posyandu ke rumah & 3 & 5,4 & 0 & 0 & 1 & 10 & 4 & 5,3 & \\
\hline
\end{tabular}

Pada sajian tabel 4, sebagian ibu tetap berpedoman dengan buku KIA sebanyak 35 (46,7\%) responden, dengan cara menimbang sendiri atau di tempat lain, mengukur tinggi badan anak dengan pita ukur dan rajin mencatat di buku KIA. Beberapa ibu menggunakan aplikasi Primaku sebanyak 11 (14,7\%) responden. Dari hasil wawancara sebagian kecil kader posyandu melakukan kunjungan rutin ke rumah dengan membawa timbangan dan alat ukur tinggi badan dan mencatat di buku KIA serta memberikan edukasi kepada ibu yakni pada $4(5,3 \%)$ responden. Beberapa ibu yakni $16(21,3 \%)$ responden tetap memeriksakan anaknya dengan berkunjung rutin ke bidan/dokter 
Jurnal SEMAR Vol. 10 No. 1, hal. $70-77$

ISSN: 2302-3937 | Copyright (C LPPM Universitas Sebelas Maret Homepage: https://jurnal.uns.ac.id/jurnal-semar

umum/dokter anak untuk pemantauan pertumbuhannya, namun demikian masih ada sebagian kecil yang hanya mengamati saja dan dibandingkan berat badan dan tinggi badan anak usia sebaya yaitu $5(6,7 \%)$ responden.

\section{Pembahasan}

Usia ibu pada penelitian ini tidak berhubungan dengan status gizi anak. Hal ini sejalan dengan penelitian sebelumnya yang menyebutkan bahwa tidak terdapat hubungan yang signifikan antara usia ibu dengan status gizi balita (Liswati, 2016). Jika dikelompokkan sesuai dengan status gizi baduta usia 4-24 bulan, ibu yang berprofesi sebagai perawat lebih banyak memiliki baduta dengan status gizi baik jika dibandingkan dengan ibu yang memiliki baduta dengan status gizi lainnya. Hasil analisis menunjukkan bahwa tidak ada hubungan signifikan antara status pekerjaan ibu dengan status gizi baduta. Hasil ini sesuai dengan penelitian yang menyebutkan bahwa tidak terdapat hubungan antara pekerjaan ibu dengan status gizi anak usia 12-36 bulan (Nugraheningtyasari, 2018).

Pendidikan ibu merupakan pendidikan terakhir yang telah ditempuh ibu saat penelitian dilakukan. Tingkat pendidikan seseorang memegang peran yang penting dalam kesehatan masyarakat, namun dalam penelitian ini ibu dengan pendidikan Sarjana masih ada yang memiliki anak dengan status gizi kurang. Jumlah ini lebih tinggi dibandingkan ibu yang mempunyai anak gizi kurang dengan tingkat pendidikan Diploma dan sekolah menegah. Hal ini sesuai dengan penelitian sebelumnya yang menyatakan bahwa tingkat pendidikan ibu tidak berhubungan secara signifikan dengan status gizi (Liswati,2016, Astuti FD, 2013). Semakin tinggi tingkat pendidikan ibu, memberikan kecenderungan semakin tinggi pula kesibukan ibu sehingga hal ini berpengaruh terhadap kurangnya perhatian dan kepedulian dalam pemantauan status gizi anak. Orangtua yang memiliki pendidikan tinggi cenderung memilih makanan dengan gizi seimbang dan memperhatikan kebutuhan gizi anak (Suhendri, 2019; Bashir, 2012). Semakin tinggi tingkat pendidikan kualitas pekerjaan yang dijalani semakin berat dan waktu yang dimiliki ibu untuk mengasuh anak disela kesibukan ibu bekerja sehingga fenomena ini justru berkaitan dengan anak yang memiliki status gizi kurang.

Pada penelitian ini menunjukkan sumber pengetahuan ibu terbanyak mengenai pemberian MP-ASI didapat dari media sosial berbagai sumber yang bervariasi validitasnya sehingga masih belum sepenuhnya tepat, namun hal ini setara dengan perolehan informasi MP-ASI dari fasilitas kesehatan yang mayoritas sudah memberikan penyuluhan yang tepat. Perolehan sumber pengetahuan ibu mengenai MP-ASI tidak berhubungan dengan status gizi anak. Berbagai penelitian sebelumnya menyatakan adanya hubungan antara tingkat pengetahuan ibu mengenai MP-ASI dengan status gizi anak (In'am M, 2016; Kusumasari, 2012; Tristanti, 2018). Namun belum ada studi yang mengkaji hubungan maupun validitas sumber informasi ibu tentang MP-ASI dengan status gizi anak. Hasil kajian Muller dan Krawinkel (2005) menyebutkan bahwa pengenalan awal terhadap makanan pertama yang rendah kualitas dan kuantitasnya, rendahnya pemberian ASI eksklusif dan tingginya frekuensi penyakit pada awal masa bayi merupakan alasan penyebab terjadinya keterlambatan pertumbuhan. Kuantitas dan kualitas makanan yang diberikan serta frekuensi makan merupakan faktor penting yang berkaitan dengan status gizi.

Studi yang dilakukan oleh Beck dan Lavender menyatakan bahwa status nutrisi tidak hanya berkaitan dengan respon imun namun juga dapat mempengaruhi patogenitas virus. Pemberian nutrisi yang tepat terutama pada masa emas anak akan sangat berdampak pada ketahanan tubuh sehingga dapat menurunkan risiko terpapar suatu infeksi (Beck dan Levander, 2000). Pemantauan pertumbuhan anak di masa pandemi Covid-19 ini menjadi hal yang sangat penting sehubungan dengan banyaknya fasilitas kesehatan dasar yang tidak membuka pelayanan secara langsung. Sajian tabel 4 menunjukkan temuan menarik mengenai hubungan signifikan antara cara pemantauan pertumbuhan (dalam hal ini berat badan maupun tinggi badan) dengan status gizi anak pada masa pandemi Covid-19 ini. Sebagian besar ibu yang selalu menggunakan buku KIA dan berkunjung rutin ke bidan/dokter umum maupun dokter anak menunjukkan anak dengan status gizi baik. Kajian ini erat kaitannya dengan parameter yang digunakan ibu secara kontinyu untuk pedoman pertumbuhan anak. Ibu yang erat dengan dunia maya sudah menggunakan aplikasi pemantauan tumbuh kembang anak yakni Primaku yang dibuat oleh IDAI, metode ini sangat mudah digunakan untuk deteksi dini adanya masalah pertumbuhan anak.

\section{Kesimpulan}

Pemantauan pertumbuhan baduta di era pandemi Covid-19 berhubungan secara signifikan dengan status gizi $(\mathrm{p}=0,010)$, meskipun tidak ada hubungan antara sumber informasi ibu tentang MP-ASI dengan status gizi baduta. 
Penyelenggaraan penyuluhan rutin serta pelatihan bagi ibu maupun kader posyandu sangat diperlukan untuk meningkatkan pengetahuan ibu mengenai MP-ASI terutama pada periode emas anak usia 4-24 bulan serta tata cara pemantauan pertumbuhan anak secara mandiri meliputi pengukuran antropometri untuk deteksi dini status gizi secara berkala pada masa pandemi Covid-19 di Solo Raya.

\section{Daftar Pustaka}

Adriani, M., Wirjatmadi, B., 2014, Peran Gizi dalam Siklus Kehidupan, Kencana Prenada Media Group, Jakarta.

Akseer N, Kandru G, Keats EC, Bhutta ZA., 2000, COVID-19 pandemic and mitigation strategies: implications for maternal and child health and nutrition. Am J Clin Nutr, Aug 1, vol 112(2), hal 251-256. doi: 10.1093/ajcn/nqaa171.PMID: 32559276 Free PMC article. Review.

Astuti FD, Fitriya T., 2013, Hubungan tingkat pendidikan ibu dan tingkat pendapatan keluarga dengan status gizi anak pra sekolah dan Sekolah Dasar di kecamatan Godean, Fakultas Ilmu Kesehatan Masyarakat, Universitas Ahmad Dahlan, Yogyakarta.

Bashir, S. S., 2012, Effect of Maternal Literacy on Nutritional Status of Children Under 5 Years of Age in the Babban-Dodo Community Zaria City Northwest Nigeria. Annals of Nigerian Medicine Journal [e-journal] 6 (2).

Beck MA, Levander OA., 2000, Host nutritional status and its effect on a viral pathogen. J. Infect, vol 182, hal $93-$ 96.

Cogill B., 2001, Anthropometry indicators measurement guide. Food and nutrition technical assistance. US agency for international.

In'am, M., 2016, Hubungan Tingkat Pengetahuan Orang Tua Dengan Status Gizi Anak Di Bawah 5 Tahun Di Posyandu Wilayah Kerja Puskesmas Nusukan Surakarta, Fakultas Kedokteran, Universitas Muhammadiyah Surakarta. Tersedia dalam 〈https//:eprints.ums.ac.id> diakses pada tanggal 7 Februari 2021.

Kusumasari FE., 2012, Hubungan Pengetahuan Ibu tentang Makanan Pendamping ASI dengan Status Gizi pada Anak di Wilayah Kerja Puskesmas Juwiring Klaten, Fakultas Ilmu Kesehatan, Universitas Muhammadiyah Surakarta.

Liswati, E. M., 2016, Hubungan Karakteristik Ibu dengan Status Gizi Anak Balita yang Memiliki Jamkesmas di Desa Tegal Gizi Kecamatan Nogosari Kabupaten Boyolali Surakarta, Program Studi Ilmu Gizi, Fakultas Ilmu Kesehatan, Universitas Muhammadiyah Surakarta.

Maqbool A,Olsen IE., 2008, Clinical assessment in nutritional status, Duggan C, Watkins JB, Walker WA, penyunting: Nutrition in Pediatric, hal 5-13, BC Decker, Ontario.

Mexitalia M, Nasar SS., 2011, Makanan Pendamping ASI, Sjarif DR, Lestari ED, Mexitalia M, Nasar SS,penyunting: Buku ajar nutrisi pediatrik dan penyakit metabolik. Cetakan Pertama, hal 117-126, Badan Penerbit IDAI, Jakarta.

Muller, O., Krawinkel, M., 2005, Malnutrition and health in developing countries. Can med. Assoc. J., 173:279286.

Nugraheningtyasari, NA, Annisa N, Susanti D., 2018, Correlation Between Nutritional Status Of Children Aged 12 - 36 Months And Mother's Working Status In Taman, Sidoarjo. Biomolecular and Health Science Journal.,01(02), hal 101-104.

Suhendri, U., 2019, Faktor-faktor yang Berhubungan dengan Status Gizi Anak Dibawah Lima Tahun (BALITA) di Puskesmas Sepatan Kecamatan Sepatan Kabupaten Tangerang Tahun, Skripsi, Universitas Islam Negeri Syarif Hidayatullah Jakarta. 2009.

Tristanti, I. (2018). Pengetahuan Ibu Tentang Makanan Pendamping Asi Bagi Bayi Umur 6-12 Bulan Ditinjau Dari Karakteristik Ibu. Jurnal Ilmu Keperawatan Dan Kebidanan, 9(1), 66. https://doi.org/10.26751/jikk.v9i1.405 